\title{
Performance Analysis of Zigbee Mesh Topology by Varying Trajectory
}

\author{
Arshdeep Singh Baath \\ Research Scholar, \\ Department of ECE, \\ SBSSTC , Ferozepur-152004, \\ Punjab ,India
}

\author{
Amit Grover \\ Assistant Professor, \\ Department of ECE, \\ SBSSTC , Ferozepur-152004, \\ Punjab ,India
}

\begin{abstract}
In this paper the effect on Zigbee mesh topology is analyzed by moving the nodes at different trajectories at different speed. The nodes are moved by using Helbert Space-filling curve, hexagon and outer square trajectory. The effect is analyzed in terms of load, delay and traffic received. Result shows that with change in trajectory the performance changes. Results have been analyzed by keeping 32 nodes fixed and all others moving at speed of $5 \mathrm{~m} / \mathrm{sec}$ and $7 \mathrm{~m} / \mathrm{sec}$. It has been concluded that the hexagon trajectory performs better as compare to square trajectory at speed of $5 \mathrm{~m} / \mathrm{sec}$ and at 7 $\mathrm{m} / \mathrm{sec}$ when 32 nodes are kept fixed and all other are moving. Further it has been investigated that while moving 32 nodes and keeping all other fixed, the performance of square trajectory is better at speed of $5 \mathrm{~m} / \mathrm{sec}$ and the performance of helbert curve is better at speed of $7 \mathrm{~m} / \mathrm{sec}$.
\end{abstract}

\section{Keywords}

WSN, ZigBee 802.15, OPNET.

\section{INTRODUCTION}

For the attributes of self-association, smaller size, minimal cost and adaptability, Wireless sensor networks is intriguing exploration topic, both in military $[1,2]$ and civilian scenarios[1, 3].Specifically, remote/ecological observing, reconnaissance of held zones and so forth, are imperative fields of utilization of wireless sensor organizing methods. Normally, low power utilization and ease hardware is required $[2,4,11]$. WSNs belong with the Wireless Personal Area Network (WPAN) sort. Here, " personal " means short range communication [1]. A WSN is a self-designing network of small sensor nodes communicating among themselves utilizing radio signals, and conveyed in quantity to sense, monitor and understand the physical world. ZigBee is an overall open standard for wireless radio networks in the checking and control fields. The standard was produced by the ZigBee Alliance to meet the accompanying essential needs like minimal cost, Integrated insight for network set-up and message routing, low data rate (under $250 \mathrm{Kbps}$ ), modest and simple establishment and ultra-low power utilization.

\section{ARCHITECTURE}

ZigBee has three layers $[3,11]$. The top layer is known as the application layer (APL). This layer gives the device its usefulness. Fundamentally, this layer changes over the input into digital information, and/or changes over digital information into output. A single device might run various applications to perform distinctive errands (i.e. reading temperature and humidity).The application layer is on top of another layer called the network layer (NWL). The network layer gives ZigBee usefulness and goes about as a buffer between application layer and data link layer (DLL). The network layer is in responsible for network structure, routing, and security, for example, encryption, key administration, and authentication. The data link layer is given by IEEE 802.15.4 standard.

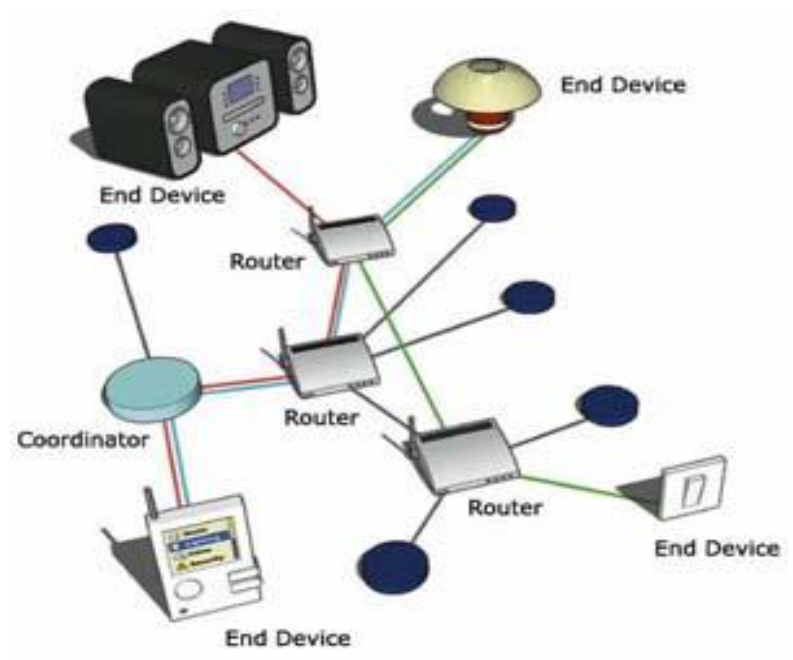

Figure 1: A typical example of ZigBee in Home Automation [5]

\section{DEVICE TYPES}

ZigBee devices are ordered as Full Functional Devices (FFD) and Reduced Functional Device (RFD). Coordinators and routers are sorted as FFD and end devices are ordered as RFD yet all have the same kind of node model. ZigBee coordinator is the most able device, the coordinator frames the root of the network tree and may extension to different networks. There is precisely one ZigBee coordinator in every network since the device began the system initially. It can store data about the network, including going about as the Trust Center and repository for security keys. ZigBee router can go about as a intermediate router, passing information to different devices. ZigBee end devices contains a usefulness to converse with the parentnode (either the organizer or a router), it can't hand-off information from different devices. This relationship permits the node to be snoozing a lot of the time along these lines giving long battery life. A ZED requires minimal measure of memory, so it can be less costly to manufacturer than a $\mathrm{ZR}$ or $\mathrm{ZC} \mathrm{[6].} \mathrm{The} \mathrm{ZigBee} \mathrm{standard} \mathrm{permits} \mathrm{the} \mathrm{arrangement} \mathrm{of} \mathrm{three}$ sorts of system topology: star, tree, and mesh[7, 13], in this research work mesh topology is utilized.

\section{MESH TOPOLOGIES}

In a network of mesh topology routers and coordinators shape various connections among one another while having enddevices as their children. While more perplexing in its development and operation, mesh topology is characterized by 
link/path redundancy which is known to in enhanced robustness and network routing capacity.

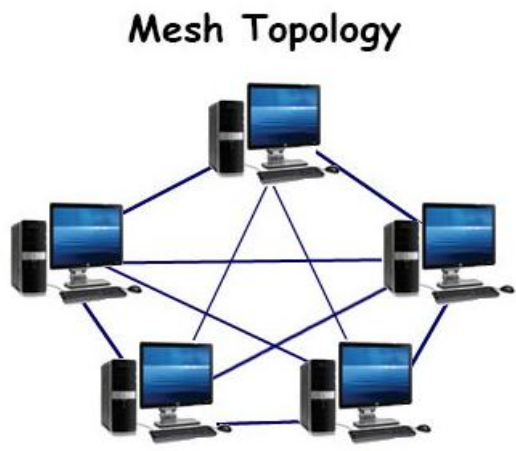

Figure 2: Mesh Topologies

\section{EXPERIMENTAL SETUP}

In this paper the effect of trajectories is analyzed on mesh topology. To analyze this effect different scenarios are used by using Helbert Space-filling curve[14], hexagon and outer square trajectory. In each scenarios 500 nodes are used which are placed randomly over an area of $2000 \mathrm{~m} * 2000 \mathrm{~m}$. In this area firstly 32 nodes are moving at different speed by using these trajectories and rest is static. In this scenarios nodes move and 8 nodes stoped at each points as shown in fig 3,4,5 and rest moves further. In other scenario 32 nodes are static and other nodes are moving at different speed by using different trajectories. In these scenarios 468 nodes moves and 117 nodes stoped at each point as shown in fig 3,4,5 and rest moved for next point. In each scenario 4 mobile coordinator is used which moves at different speed by using different trajectories. These 4 coordinator moves and 1 coordinator stop at each point. In each scenario 32 routers are used which are placed randomly.

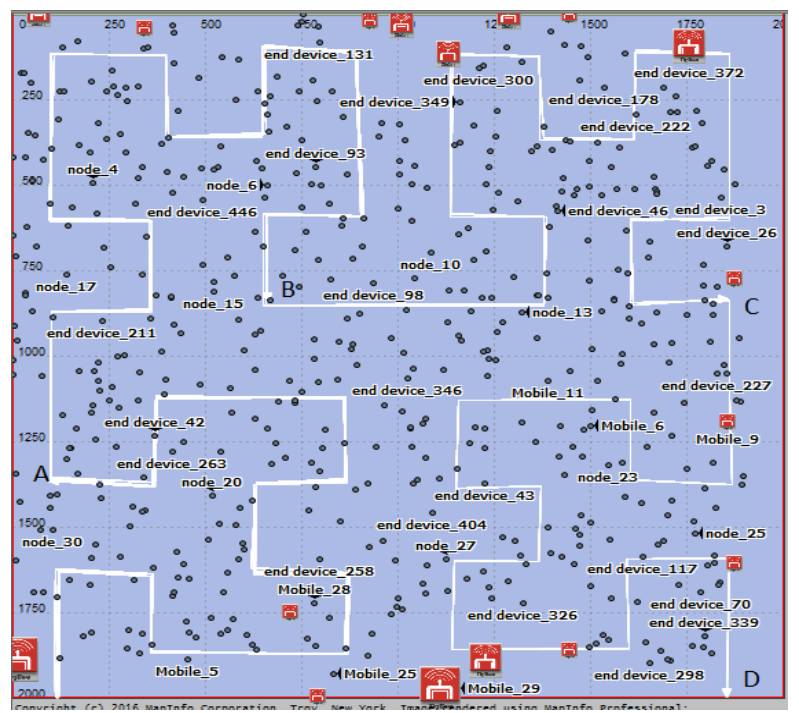

Figure 3: Helbert curve

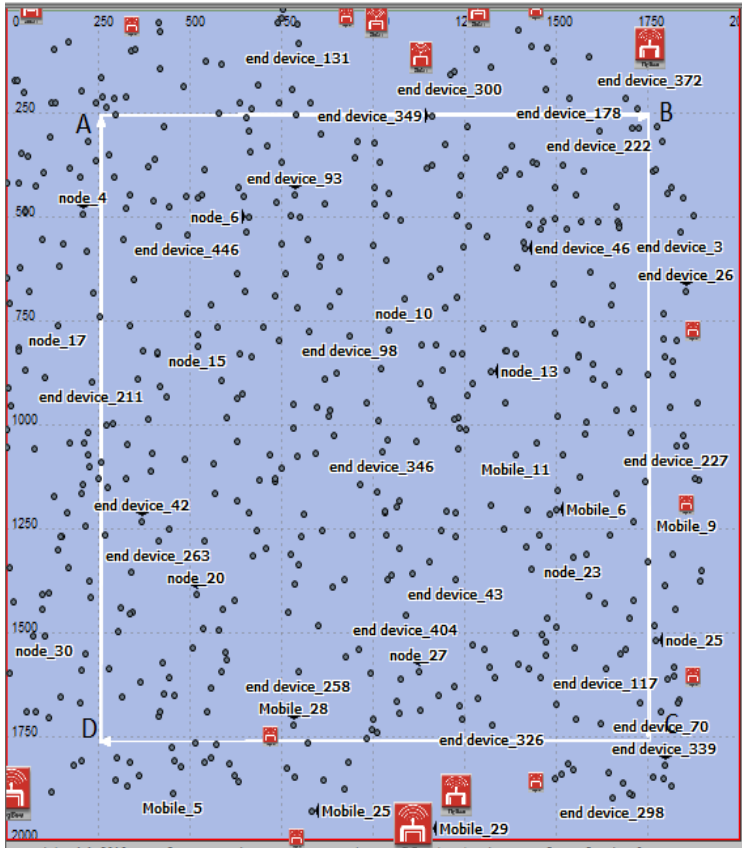

Figure 4: Square Trajectory

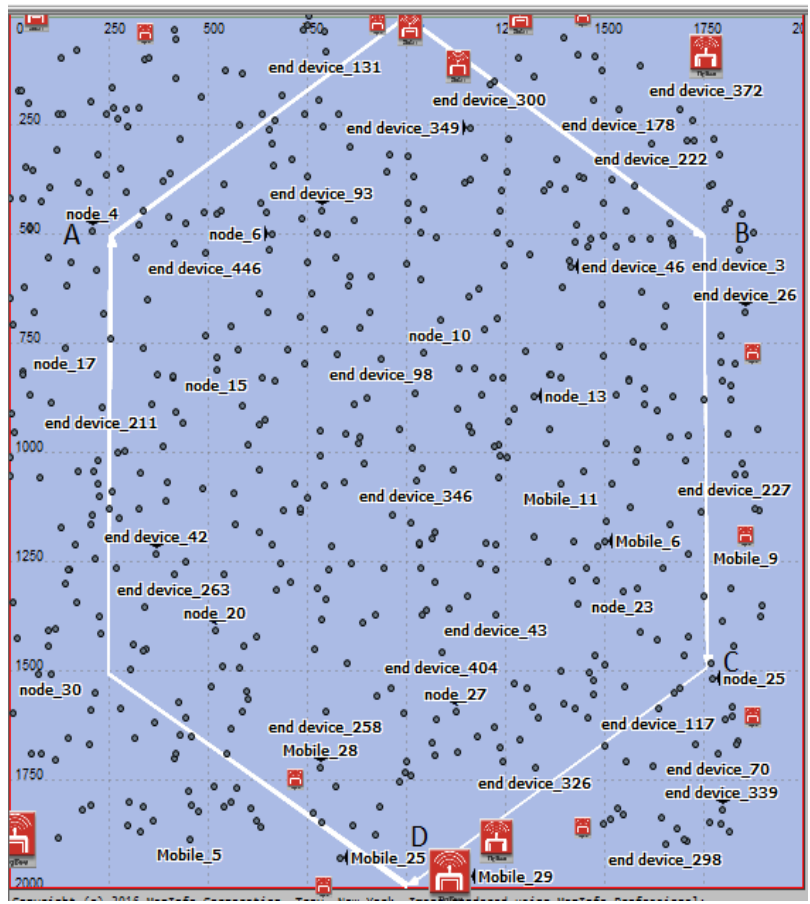

Figure 5: Hexagon Trajectory

\section{RESULTS}

Here performance of Mesh is analyzed with the mobility of both ZigBee End Devices and ZigBee coordinator for different trajectories. The result is analyzed in terms of Delay Traffic Received and Load. 


\subsection{Delay}

average (in ZigBee 802_15_4 MAC.Delay (sec))

口 arsh-helbert 51-DES-1

$\square$ arsh-helbert 7 2-DES-1

$\square$ arsh-hex 51-DES-1

$\square$ arsh-hex 7 -DES-1

$\square$ arsh-square 51-DES-1

a arsh-square7 1-DES-1

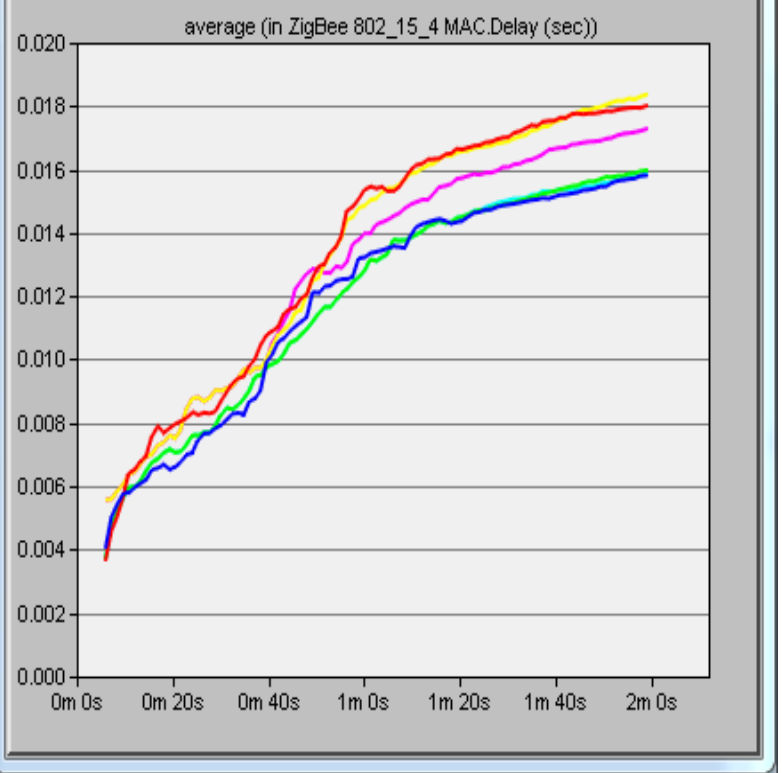

Figure 6: Delay when 32 nodes moves

* average (in ZigBee 802_15_4 MAC.Delay (sec)) $\square$ 回 23

a arsh-helbert 5 fix 2-DES-1

$\square$ arsh-helbert 7 fix 1 -DES-1

$\square$ arsh-hex 5 fix -DES-1

$\square$ arsh-hex 7 fix 1 -DES-1

$\square$ arsh-square 5 fix 2-DES-1

$\square$ arsh-square 7 fix 3-DES-1

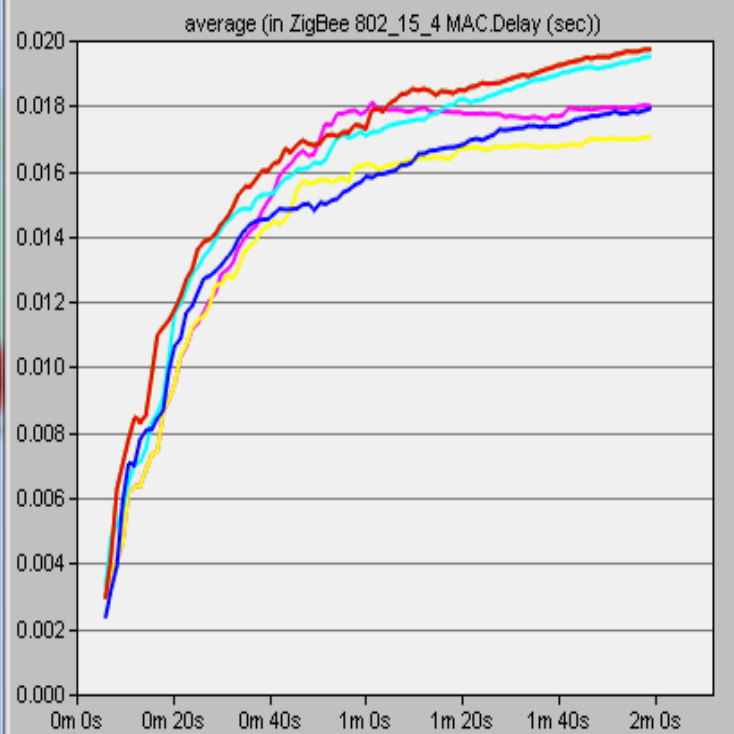

Figure 7: Delay when 32 nodes fix

Fig6 shows the results of delay for helbert curve, hexagon trajectory and square trajectory when 32 nodes moves with speed of $5 \mathrm{~m} / \mathrm{sec}$ and $7 \mathrm{~m} / \mathrm{sec}$ and all other nodes are fixed Results shown in fig 6 are given in table1.

Table 1: Delay when 32 nodes moves

\begin{tabular}{|l|l|l|l|}
\hline Speed & \multicolumn{1}{|c|}{$\begin{array}{c}\text { Helbert } \\
\text { Curve } \\
\text { (Delay) }\end{array}$} & $\begin{array}{c}\text { Hexagonal } \\
\text { Trajectory } \\
\text { (Delay) }\end{array}$ & $\begin{array}{c}\text { Square } \\
\text { Trajec- } \\
\text { tory } \\
\text { (Delay) }\end{array}$ \\
\hline $\begin{array}{l}5 \mathrm{~m} / \\
\mathrm{sec}\end{array}$ & $0.016 \mathrm{sec}$ & $0.016 \mathrm{sec}$ & $0.019 \mathrm{sec}$ \\
\hline $\begin{array}{l}7 \mathrm{~m} / \\
\mathrm{sec}\end{array}$ & $0.018 \mathrm{sec}$ & $0.016 \mathrm{sec}$ & $\begin{array}{l}0.017 \\
\mathrm{sec}\end{array}$ \\
\hline
\end{tabular}

Fig7 shows the results of delay for helbert curve, hexagon trajectory and square trajectory when 32 nodes are fixed and all other nodes are moving with speed of $5 \mathrm{~m} / \mathrm{sec}$ and $7 \mathrm{~m} / \mathrm{sec}$ . Results shown in fig 7 are given in table2.

Table 2: Delay when 32 nodes fix

\begin{tabular}{|c|c|c|c|}
\hline Speed & $\begin{array}{c}\text { Helbert } \\
\text { Curve } \\
\text { (Delay) }\end{array}$ & $\begin{array}{c}\text { Hexagonal } \\
\text { Trajectory } \\
\text { (Delay) }\end{array}$ & $\begin{array}{c}\text { Square } \\
\text { Trajec- } \\
\text { tory } \\
\text { (Delay) }\end{array}$ \\
\hline $5 \mathrm{~m} /$ & $0.018 \mathrm{sec}$ & $0.019 \mathrm{sec}$ & $0.017 \mathrm{sec}$ \\
$\mathrm{sec}$ & & & \\
\hline $7 \mathrm{~m} /$ & $0.020 \mathrm{sec}$ & $0.020 \mathrm{sec}$ & 0.018 \\
$\mathrm{sec}$ & & & $\mathrm{sec}$ \\
\hline
\end{tabular}

\subsection{Traffic received}

A average (in ZigBee 802_15_4 MAC.Data Traffic Rcvd (bit... $\square$ 回 XS

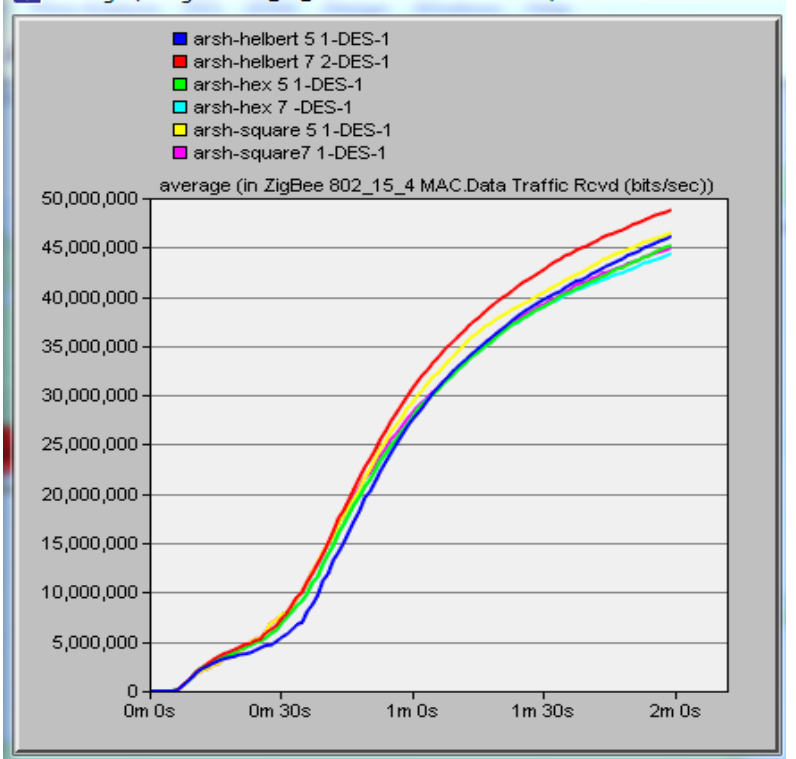

Figure 8: Traffic received when 32 nodes moves 
average (in ZigBee 802_15_4 MAC.Data Traffic Rcvd (bit....

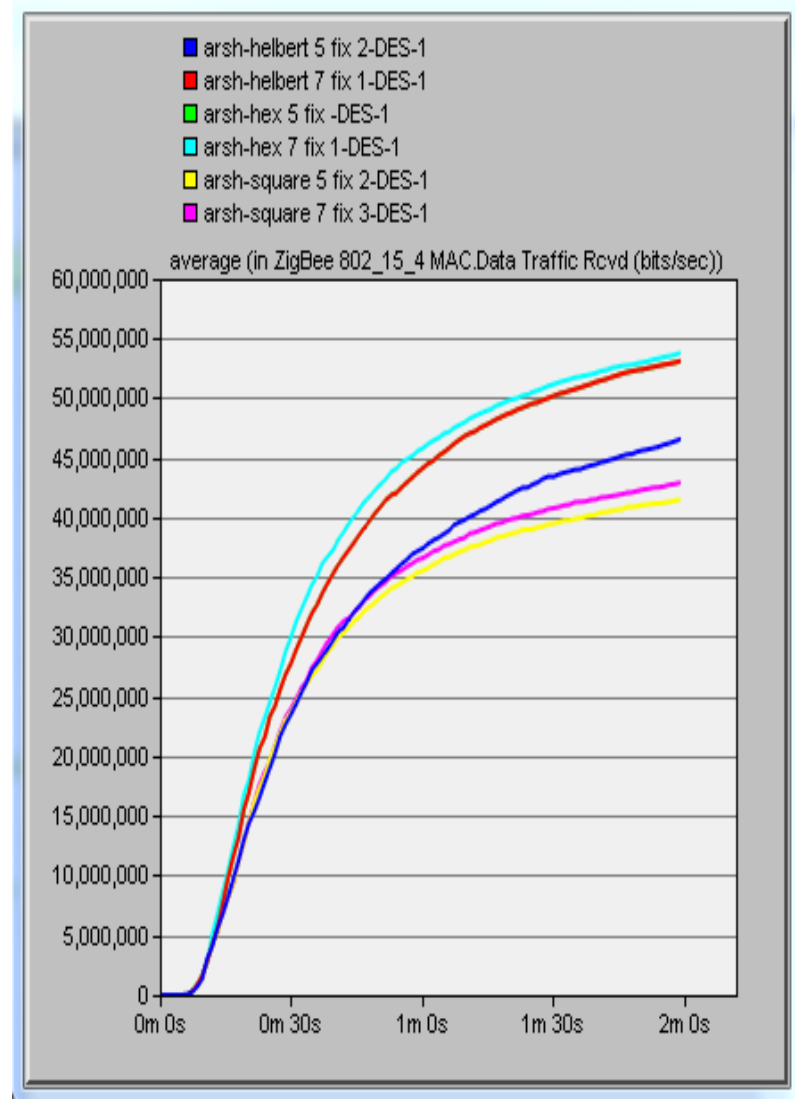

Figure 9: Traffic received when 32 nodes Fix

Fig8 shows the results of Traffic received for helbert curve, hexagon trajectory and square trajectory when 32 nodes moves with speed of $5 \mathrm{~m} / \mathrm{sec}$ and $7 \mathrm{~m} / \mathrm{sec}$ and all other nodes are fixed. Results shown in fig 8 are given in table 3 .

Table 3: Traffic received when 32 nodes moves

\begin{tabular}{|l|l|l|l|}
\hline Speed & $\begin{array}{c}\text { Helbert } \\
\text { Curve } \\
\text { (Traffic } \\
\text { received) }\end{array}$ & $\begin{array}{c}\text { Hexagonal } \\
\text { Trajectory } \\
\text { (Traffic } \\
\text { received) }\end{array}$ & $\begin{array}{c}\text { Square } \\
\text { Traject-ory } \\
\text { (Traffic } \\
\text { received) }\end{array}$ \\
\hline $5 \mathrm{~m} / \mathrm{sec}$ & $\begin{array}{l}46000000 \\
\text { bits/sec }\end{array}$ & $\begin{array}{l}45000000 \\
\text { bits/sec }\end{array}$ & $\begin{array}{l}46000000 \\
\text { bits } / \mathrm{sec}\end{array}$ \\
\hline $7 \mathrm{~m} / \mathrm{sec}$ & $\begin{array}{l}49000000 \\
\text { bits/sec }\end{array}$ & $\begin{array}{l}44000000 \\
\text { bits/sec }\end{array}$ & $\begin{array}{l}45000000 \\
\text { bits } / \mathrm{sec}\end{array}$ \\
\hline
\end{tabular}

Fig9 shows the results of Traffic received for helbert curve, hexagon trajectory and square trajectory when 32 nodes are fixed and all other nodes are moving with speed of $5 \mathrm{~m} / \mathrm{sec}$ and $7 \mathrm{~m} / \mathrm{sec}$. Results shown in fig 9 are given in table 4 .
Table 4: Traffic received when 32 nodes Fix

\begin{tabular}{|l|l|l|l|}
\hline Speed & $\begin{array}{c}\text { Helbert } \\
\text { Curve } \\
\text { (Traffic } \\
\text { received) }\end{array}$ & $\begin{array}{c}\text { Hexagonal } \\
\text { Trajectory } \\
\text { (Traffic } \\
\text { received) }\end{array}$ & $\begin{array}{c}\text { Square } \\
\text { Trajectory } \\
\text { (Traffic } \\
\text { received) }\end{array}$ \\
\hline $5 \mathrm{~m} / \mathrm{sec}$ & $\begin{array}{l}46000000 \\
\text { bits/sec }\end{array}$ & $\begin{array}{l}54000000 \\
\text { bits/sec }\end{array}$ & $\begin{array}{l}41000000 \\
\text { bits/sec }\end{array}$ \\
\hline $7 \mathrm{~m} / \mathrm{sec}$ & $\begin{array}{l}53000000 \\
\text { bits/sec }\end{array}$ & $\begin{array}{l}54000500 \\
\text { bits } / \mathrm{sec}\end{array}$ & $\begin{array}{l}42000000 \\
\text { bits/sec }\end{array}$ \\
\hline
\end{tabular}

\subsection{LOAD}

Represents the total load (in bits/sec) submitted to 802.15.4 MAC by all higher layers in all WPAN nodes of the network.

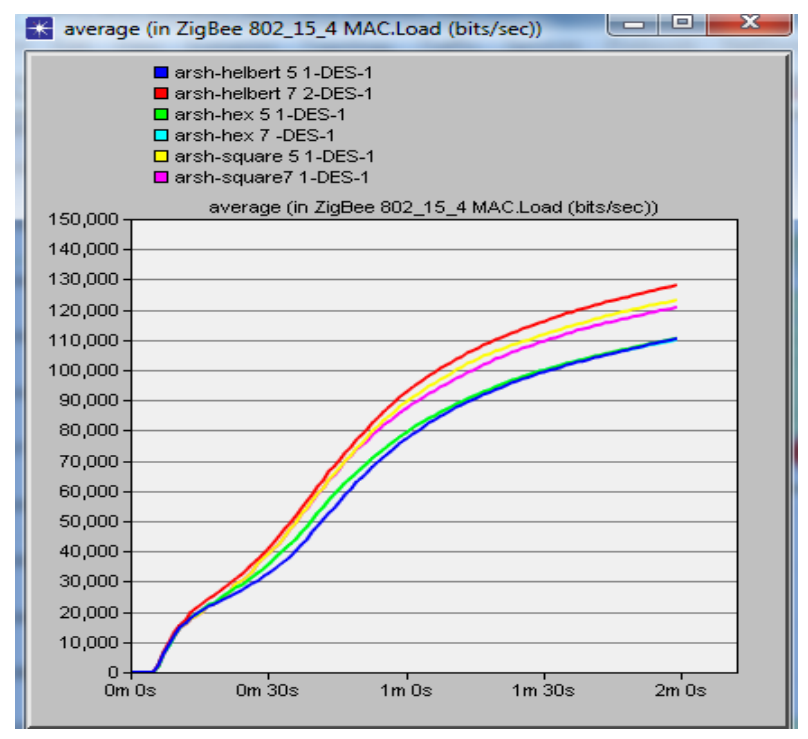

Figure 10: Load when 32 nodes moves

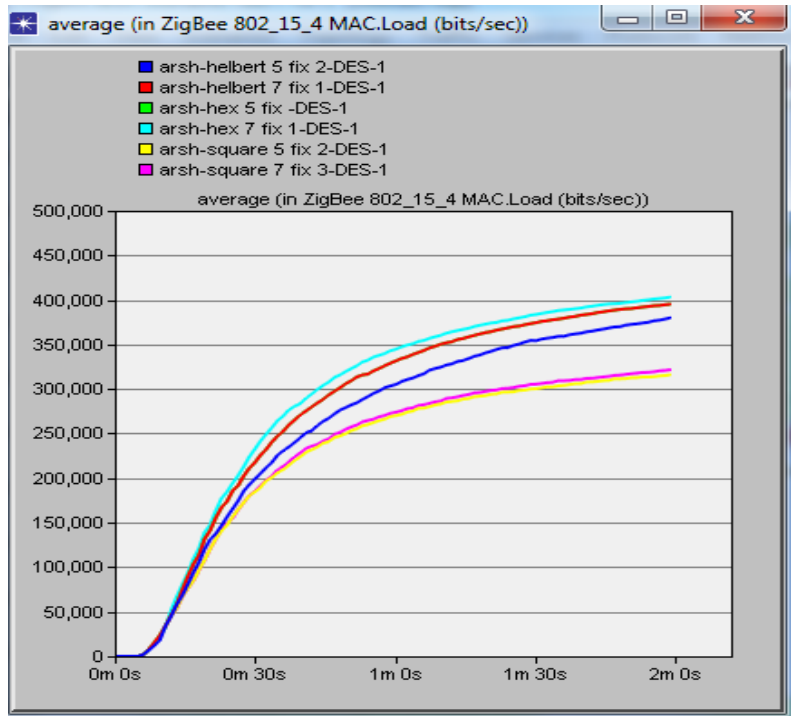

Figure 11: Load when 32 nodes Fix

Fig10 shows the results of Load for helbert curve, hexagon trajectory and square trajectory when 32 nodes moves with speed of $5 \mathrm{~m} / \mathrm{sec}$ and $7 \mathrm{~m} / \mathrm{sec}$ and all other nodes are fixed Results shown in fig 10 are given in table5. 
Table 5: Load when 32 nodes moves

\begin{tabular}{|c|l|l|c|}
\hline Speed & \multicolumn{1}{|c|}{$\begin{array}{c}\text { Helbert } \\
\text { Curve } \\
\text { (Load) }\end{array}$} & $\begin{array}{c}\text { Hexagonal } \\
\text { Trajectory } \\
\text { (Load) }\end{array}$ & $\begin{array}{c}\text { Square } \\
\text { Trajec- } \\
\text { tory } \\
\text { (Load) }\end{array}$ \\
\hline $5 \mathrm{~m} / \mathrm{sec}$ & $\begin{array}{l}110000 \\
\mathrm{bits} / \mathrm{sec}\end{array}$ & $\begin{array}{l}110000 \\
\mathrm{bits} / \mathrm{sec}\end{array}$ & $\begin{array}{l}125000 \\
\mathrm{bits} / \mathrm{sec}\end{array}$ \\
\hline $7 \mathrm{~m} / \mathrm{sec}$ & $\begin{array}{l}130000 \\
\mathrm{bits} / \mathrm{sec}\end{array}$ & $\begin{array}{l}110000 \\
\text { bits/sec }\end{array}$ & $\begin{array}{l}120000 \\
\mathrm{bits} / \mathrm{sec}\end{array}$ \\
\hline
\end{tabular}

Fig11 shows the results of Traffic received for helbert curve, hexagon trajectory and square trajectory when 32 nodes are fixed and all other nodes are moving with speed of $5 \mathrm{~m} / \mathrm{sec}$ and $7 \mathrm{~m} / \mathrm{sec}$. Results shown in fig 11 are given in table 6.

Table 6: Load when 32 nodes Fix

\begin{tabular}{|c|l|l|l|}
\hline Speed & $\begin{array}{c}\text { Helbert } \\
\text { Curve } \\
\text { (Load) }\end{array}$ & $\begin{array}{c}\text { Hexagonal } \\
\text { Trajectory } \\
\text { (Load) }\end{array}$ & $\begin{array}{c}\text { Square } \\
\text { Trajec- } \\
\text { tory } \\
\text { (Load) }\end{array}$ \\
\hline $5 \mathrm{~m} / \mathrm{sec}$. & $\begin{array}{l}380000 \\
\text { bits/sec }\end{array}$ & $\begin{array}{l}400000 \\
\text { bits } / \mathrm{sec}\end{array}$ & $\begin{array}{l}320500 \\
\text { bits/sec }\end{array}$ \\
\hline $7 \mathrm{~m} / \mathrm{sec}$ & 400000 & 400500 & 330000 \\
& bits/sec & bits $/ \mathrm{sec}$ & $\mathrm{bits} / \mathrm{sec}$ \\
\hline
\end{tabular}

\section{CONCLUSION AND FUTURE SCOPE}

In this paper the effect of trajectories is analyzed on mesh topology by moving nodes at different speed. To analyze the effect 500 nodes are used which are placed randomly and some nodes move by using different trajectories at different speed. Trajectories used are helbert Space-filling curve, hexagon and outer square trajectory. The performance is analyzed in terms of Delay, load and traffic received. Result shows that with change in trajectory the performance changes. Results have been analyzed by keeping 32 nodes fixed and all others moving at speed of $5 \mathrm{~m} / \mathrm{sec}$ and $7 \mathrm{~m} / \mathrm{sec}$. It has been concluded that the hexagon trajectory performs better as compare to square trajectory at speed of $5 \mathrm{~m} / \mathrm{sec}$ and at 7 $\mathrm{m} / \mathrm{sec}$ when 32 nodes are kept fixed and all other are moving. Further it has been investigated that while moving 32 nodes and keeping all other fixed, the performance of square trajectory is better at speed of $5 \mathrm{~m} / \mathrm{sec}$ and the performance of helbert curve is better at speed of $7 \mathrm{~m} / \mathrm{sec}$.Result also shows with increase in speed performance increases.

\section{REFERENCES}

[1] A. Pennacchia, P. Mazzolai and P. Dario, "Development of a Programmable Sensor Interface for Wireless Network Nodes for Intelligent Agricultural Applications," Proceedings of IE, IEEE Computer and Communications Societies, Sydney, 2005, pp. 1-6.
[2] Yu Chengbo et al, " Reaserch and Application on the coverage range of the ZigBee Protocol", IEEE ,Beijing,20-21,Sept. 2009,pp. 1-4.

[3] Boris Mihajlov et al., "Overview and Analysis of the Performances of ZigBee based Wireless Sensor Networks", International Journal of Computer Applications Volume 29- No.12,2011, pp. 0975-8887.

[4] Yu-Kai Huang et al. "Distributed Throughput Optimization for ZigBee Cluster-Tree Network" IEEE Transaction On Parallel and Distributed Systems, VOL. 23- No.3, 2012,pp. 513-520.

[5] K. Konstantinos, X. Apostolos, K. Panagiotis and S. George, "Topology Optimization in Wireless Sensor Networks for Precision Agriculture Applications," Sensor Technologies and applications, Velencia, 14- 20 Oct 2007, pp. 526-530.

[6] I.S. Hammodi et al, "A comprehensive performance study of OPNET modeler for ZigBee WSN" IEEE, Cardiff,Wales,15-18 Sept.2009, pp. 357-362.

[7] Harsh Dhaka et al,"Impact of Coordinator Mobility on the throughput in a Zigbee Mesh Networks" IEEE,Patiala,19-20 Feb. 2010,pp. 279-284.

[8] Ms. Sonal J. Rane, "A Simulation Study of Behaviour of Mobile Zigbee Node" (IJSRET) Volume 1Issue6,September 2012, pp. 001-003.

[9] S. R. Ramyah , "Load Density Analysis of Mobile Zigbee Coordinator in Hexagonal Configuration" Wireless Sensor Network, Vol. 4- No. 3,2012,pp. 5964.

[10] Neeti Bisht, et al, "Mobility Based Performance Analysis of Wireless Sensor Networks" International Journal of Computer, Electronics \& Electrical Engineering , Volume 2- Issue 2, 21 Oct. 2010,pp. 15-20.

[11] M. A. M. Vieira, C. N. Coelho, D. C. Jr. Silva and J. M. Mata, "Survey on Wireless Sensor Network Devices," IEEE Conference on Emerging Technologies and Factory Automation Proceedings, Vol. 1, 16-19 Sept. 2003, pp. 537-544.

[12] J. S. Choi and M. Zhou, "Performance Analysis of Zigbee-based body sensor networks," Systems Man and Cybernetics IEEE International Conference, Istanbul, 1013 Oct. 2010, pp. 2427-2433.

[13] Y. Gu, A. Lo, and I. G. Niemegeers, "A survey of indoor positioning systems for wireless personal networks," IEEE Communications Surveys \& Tutorials, vol. 11- no. 1, First Quarter 2009, pp. 13-32.

[14] Ghafoor, Saim, et al. "An efficient trajectory design for mobile sink in a wireless sensor network." Computers \& Electrical Engineering, Vol. 40-no.7 ,Oct. 2014, pp. 2089-2100 